\title{
Consumers' Perception towards Branded Fast Food Restaurants - A Study in Erode City
}

\author{
${ }^{1}$ Dr.P.Janaki, ${ }^{2}$ Ms.B.Sindhu \\ ${ }^{1}$ Associate Professor and Head, Department of Commerce (B\&I), Vellalar College for Women \\ (Autonomous),Erode, Tamil Nadu, India \\ ${ }^{2}$ Ph.D Research scholar, PG and Research Department of Commerce, Vellalar College for Women
}

(Autonomous),Erode, TamilNadu, India.

\begin{abstract}
Fast food restaurant is one of the fastest-growing industry in India. The people prefer fast food restaurants for their convenience, time saving and relaxing dining experience. The lifestyle of the people is changing in day-to-day life which results in increasing number of people to choose fast food restaurants. Initially fast food restaurants faced assertive challenges in getting accepted by consumers due to cultural mismatch. Today, fast food industry is being fitted to food concern and is welcomed by public as well as getting famous by the country. Fast food chains are achieving acclaim among the youngsters. A firm can satisfy the customer by meeting the specific expectations of the product they have by virtue of interaction with the firm. A model of customer perception varies across firms depending on the product they offer. All the components or the attributes should focus on the quality, core service or the value. The customers experience these states as an emotion of delight. In order to increase the customer delight, the firm needs experience based expectations rather than the normal expectations. In this aspect, the study has made an attempt to analyse the consumers' perception towards branded fast food restaurants in Erode city.
\end{abstract}

Keywords - Consumer Perception, Food Restaurants, industry.

\section{INTRODUCTION}

The colourful appearances of fast food restaurants edify their rapid spreads which make them very easy to identify in the major cities and some towns of the country. Today, the list of brand names in the industry is being extended, so far without an end in sight as high sales volume encourage new entrant to spring up incessantly. The level of competition in the fast food industry is only rivalled by that in the telecommunications and banking industries, as fast food restaurants concentrated in a particular surface in every environment considered viable to capture the market ahead of others. However, with the upsurge in the setting up fast food restaurants, retaining customers becomes an issue in particular when factors such as quality and safety are important consumer concerns. The companies are spending substantial resources to measure and manage their customer satisfaction. As competition and other environmental influences increase globally, there is growing emphases on quality improvement and cost reduction in companies to achieve customer satisfaction and enhance organizational value. Many companies and organizations have come to acknowledge the critical importance of being customeroriented and customer-driven in all their activities.
The fast food industry is a product-offering as well as service-rendering industry. It poses a fundamental challenge for the management of fast food industry. and service quality is more difficult to measure than measuring product quality. The industry is closely linked to the hospitality and health care industry where high quality product/ service cannot be compromised or satisfied. Therefore, the failure of any firm to meet the required level of expectation may spell doom for the outfit. Thus, there is need to identify the consumers' perception towards branded fast food restaurant in order to ensure high customers satisfaction and continuous patronage.

\section{STATEMENT OF THE PROBLEM}

The consumer's tastes and needs are dynamic, implying that every brand should constantly find the ways to offer freshness in order to remain relevant in the market place. The restaurant industry is no longer divided into clear-cut segments since the services offered may sometimes overlap. Many of the fast food restaurants offer similar products or services. Therefore, the way and manner their services are provided are critical in gaining competitive edge.

Eating at home remains very much ingrained in Indian culture and changes in eating habits are very slow moving. The growth in nuclear families, particularly in urban India, 
exposure to global media and western cuisine and an increasing number of women joining the workforce, had an impact on eating out trends. The working people are not much interested in spending a lot of time for preparation of meals, travelling to pick up meals, or waiting for meals in restaurants. As a result, consumers rely on fast food. Knowing this, fast food providers are coming up with new ways to market their products that save time for consumers.

In such a competitive industry, marketers and business owners needs to be updated with consumer perceptions of many aspects of their business. A consumer perception has been the subject of increasing interest, especially in the service industry. Thus, it has made significant for the research to focus on consumers' perception towards branded fast food restaurants in Erode city. This study provides answer for the following questions:

- How far the respondents have awareness on the branded fast food restaurants?

- What are the factors influencing the consumers to prefer branded fast food restaurants?

- What are the perceptions of the consumers towards branded fast food restaurants?

\section{OBJECTIVES OF THE STUDY}

The main objectives of the study are,

- To know the factors influencing the consumers towards branded fast food restaurants in Erode city.

- To study the perception of consumers regarding branded fast food restaurants in Erode city.

- To offer suitable suggestions based on the findings of the study.

\section{SCOPE OF THE STUDY}

\section{RESULTS AND DISCUSSION}

The following are the findings of the study:

\section{Profile of the Respondents - Simple Percentage Analysis}

In order to have knowledge on the profile of the respondents, it has been analysed by employing simple percentage analysis. The profile of the respondents has been classified as socio-economic profile and profile based on study related variables. It is shown in the following Table 1.

TABLE 1

\begin{tabular}{|c|c|c|}
\hline Gender & Number of Respondents & Percentage (\%) \\
\hline Male & 95 & 47.5 \\
\hline Female & 105 & 52.5 \\
\hline Total & 200 & 100 \\
\hline Age & Number of Respondents & Percentage $(\%)$ \\
\hline Upto 20 years & 43 & 21.5 \\
\hline 21 - 30 years & 58 & 29 \\
\hline $31-40$ years & 53 & 26.5 \\
\hline Above 40 years & 46 & 23 \\
\hline Total & 200 & 100 \\
\hline Marital Status & Number of Respondents & Percentage $(\%)$ \\
\hline Married & 95 & 47.5 \\
\hline Unmarried & 105 & 52.5 \\
\hline Total & 200 & 100 \\
\hline
\end{tabular}




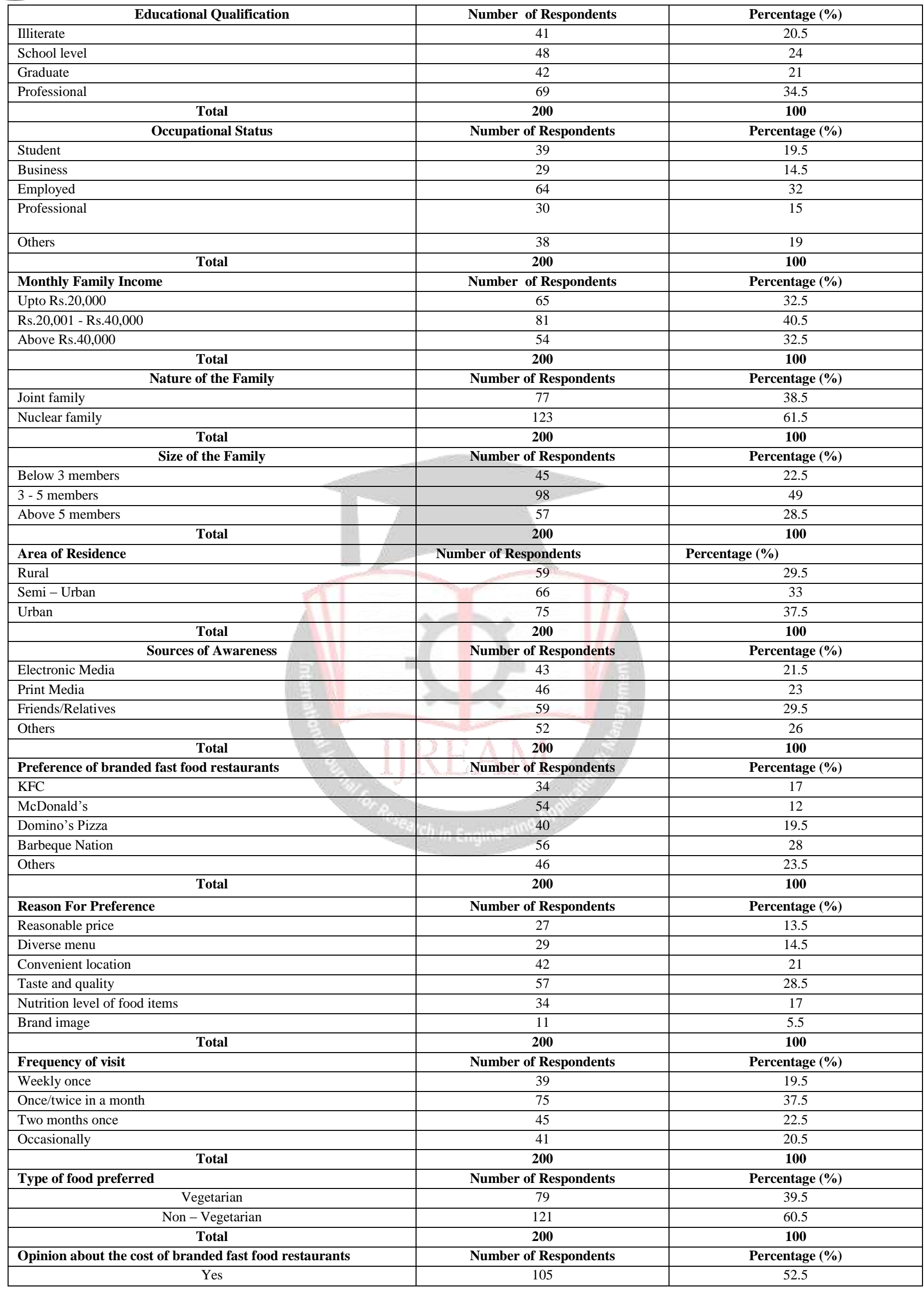




\begin{tabular}{|c|c|c|}
\hline No & 95 & 47.5 \\
\hline Total & 200 & 100 \\
\hline Consumers implications for improvements & Number of Respondents & Percentage (\%) \\
\hline Improved seating space & 13 & 6.5 \\
\hline Indication of nutritional value of items & 25 & 12.5 \\
\hline Increased variety of menu items & 38 & 19 \\
\hline More choices of healthy menu & 41 & 20.5 \\
\hline Ethnic/Local food & 48 & 24 \\
\hline Increased number of service (for e.g. Home delivery) & 35 & 17.5 \\
\hline $\begin{array}{c}\text { Total } \\
\end{array}$ & 200 & 100 \\
\hline Problems towards branded fast food restaurants & Number of Respondents & Percentage (\%) \\
\hline Yes & 188 & 94 \\
\hline No & 12 & 6 \\
\hline Total & 200 & 100 \\
\hline
\end{tabular}

The socio-economic profile of the respondents indicates that,

$>$ The majority (52.5) of the respondents are female.

$>$ The majority (29\%) of the respondents comes under the age group of 21-30 years.

$>$ The majority $(52.5 \%)$ of the respondents are unmarried.

$>$ The majority $(34.5 \%)$ of the respondents are professional.

$>$ The majority $(32 \%)$ of the respondents are employed.

$>$ The majority (40.5\%) of the respondents monthly income ranges from Rs. 20,001 - Rs.40,000.

$>$ The majority $(61.5 \%)$ of the respondents belongs to the nuclear family.

$>$ The majority (49\%) of the respondents belongs to the family size of 3-5 members.

$>$ The majority $(37.5 \%)$ of the respondents are in urban area.

The profile of the respondents based on study related variables indicates that,

$>$ The majority $(29.5 \%)$ of the respondents are aware of the branded fast food restaurants through friends and relatives.

$>$ The majority of $(28 \%)$ of the respondents mostly prefer Barbeque Nation.

$>$ The majority $(28.5 \%)$ of the respondents prefer branded fast food restaurants for taste and quality.

$>$ The majority $(37.5 \%)$ of the respondents visit the branded fast food restaurants once/twice in a month.

$>$ The majority (60.5) of the respondents prefer non-vegetarian food items in branded fast food restaurants.

$>$ The majority $(52.5 \%)$ of the respondents' opinion about the cost of branded fast food restaurants is too expensive.

$>$ The majority $(24 \%)$ of the respondents are suggesting to Ethic/ Local food.

$>$ The majority $(94 \%)$ of the respondents are facing problems towards branded fast food restaurants.

Factors Influencing to Prefer Branded Fast Food Restaurants - Henry Garrett Ranking Technique

The factors influencing the consumers' preference towards branded fast food restaurants is then analysed by applying Henry Garrett Ranking Technique. The ranking of the factors influencing the consumers' preference towards branded fast food restaurants is shown in Table 2.

\section{TABLE 2 FACTORS INFLUENCING TO PREFER THE BRANDED FAST FOOD RESTAURANTS - HENRY GARRETT'S RANKING TECHNIQUE}

\begin{tabular}{|c|c|c|c|c|c|c|c|c|c|c|c|c|c|c|c|c|c|c|}
\hline \multirow{2}{*}{\multicolumn{2}{|c|}{ Factors }} & \multicolumn{13}{|c|}{ Scale and score value of ranks } & \multirow[t]{2}{*}{ Total } & \multirow{2}{*}{$\begin{array}{l}\text { Total } \\
\text { Score }\end{array}$} & \multirow{2}{*}{$\begin{array}{l}\text { Mean } \\
\text { Score }\end{array}$} & \multirow[t]{2}{*}{ Rank } \\
\hline & & $\begin{array}{c}I \\
84\end{array}$ & $\begin{array}{l}\text { II } \\
76\end{array}$ & $\begin{array}{l}\text { III } \\
67\end{array}$ & $\begin{array}{l}\text { IV } \\
62\end{array}$ & $\begin{array}{c}\mathrm{V} \\
58\end{array}$ & $\begin{array}{l}\text { VI } \\
53\end{array}$ & $\begin{array}{c}\text { VII } \\
\mathbf{5 0}\end{array}$ & $\begin{array}{c}\text { VIII } \\
46\end{array}$ & $\begin{array}{l}\text { IX } \\
42\end{array}$ & $\begin{array}{c}X \\
37\end{array}$ & $\begin{array}{l}\text { XI } \\
33\end{array}$ & $\begin{array}{c}\text { XII } \\
26\end{array}$ & $\begin{array}{c}\text { XIII } \\
16\end{array}$ & & & & \\
\hline \multirow{2}{*}{$\begin{array}{l}\text { Food served in } \\
\text { hot and fresh } \\
\text { manner }\end{array}$} & $F$ & 21 & 29 & 10 & 30 & 21 & 14 & 11 & 3 & 8 & 15 & 14 & 7 & 17 & \multirow[t]{2}{*}{200} & \multirow[t]{2}{*}{10953} & \multirow[t]{2}{*}{54.76} & \multirow[t]{2}{*}{ IV } \\
\hline & FX & 1764 & 2204 & 670 & 1860 & 1218 & 742 & 550 & 138 & 336 & 555 & 432 & 182 & 272 & & & & \\
\hline \multirow[t]{2}{*}{ Reasonable price } & $\mathrm{F}$ & 5 & 10 & 5 & 12 & 5 & 12 & 23 & 21 & 16 & 26 & 20 & 28 & 17 & \multirow[t]{2}{*}{200} & \multirow[t]{2}{*}{8595} & \multirow[t]{2}{*}{42.97} & \multirow[t]{2}{*}{ XIII } \\
\hline & FX & 420 & 760 & 335 & 744 & 290 & 636 & 1150 & 966 & 672 & 962 & 660 & 728 & 272 & & & & \\
\hline \multirow{2}{*}{$\begin{array}{l}\text { Pleasant odour in } \\
\text { the restaurant }\end{array}$} & $\mathrm{F}$ & 17 & 24 & 16 & 11 & 16 & 9 & 13 & 10 & 5 & 21 & 10 & 20 & 28 & \multirow[t]{2}{*}{200} & \multirow[t]{2}{*}{9758} & \multirow[t]{2}{*}{48.79} & \multirow[t]{2}{*}{ VII } \\
\hline & FX & 1428 & 1824 & 1072 & 682 & 928 & 477 & 650 & 460 & 210 & 777 & 330 & 520 & 400 & & & & \\
\hline \multirow{2}{*}{$\begin{array}{l}\text { Hand wash and } \\
\text { dinning are kept } \\
\text { clean }\end{array}$} & $\mathrm{F}$ & 7 & 11 & 20 & 12 & 10 & 25 & 17 & 26 & 16 & 20 & 13 & 13 & 10 & \multirow[t]{2}{*}{200} & \multirow[t]{2}{*}{9798} & \multirow[t]{2}{*}{48.99} & \multirow[t]{2}{*}{ VI } \\
\hline & FX & 588 & 836 & 1340 & 744 & 580 & 1325 & 850 & 1196 & 672 & 740 & 429 & 338 & 160 & & & & \\
\hline \multirow{2}{*}{$\begin{array}{l}\text { Adequate } \\
\text { number of } \\
\text { suppliers for } \\
\text { customers }\end{array}$} & $\mathrm{F}$ & 18 & 23 & 23 & 13 & 18 & 25 & 2 & 12 & 15 & 23 & 5 & 14 & 9 & \multirow[t]{2}{*}{200} & \multirow[t]{2}{*}{10782} & \multirow[t]{2}{*}{53.91} & \multirow[t]{2}{*}{$\mathrm{V}$} \\
\hline & FX & 1512 & 1748 & 1541 & 806 & 1044 & 1325 & 100 & 552 & 630 & 851 & 165 & 364 & 144 & & & & \\
\hline \multirow[t]{2}{*}{ Delivery time } & $\mathrm{F}$ & 5 & 6 & 11 & 13 & 10 & 16 & 19 & 15 & 27 & 20 & 22 & 26 & 10 & 200 & 8923 & 44.61 & $\mathrm{XI}$ \\
\hline & FX & 420 & 456 & 737 & 806 & 580 & 848 & 950 & 690 & 1134 & 740 & 726 & 676 & 160 & & & & \\
\hline Quick & $\mathrm{F}$ & 1 & 6 & 10 & 17 & 25 & 12 & 32 & 21 & 21 & 8 & 17 & 17 & 13 & 200 & 9305 & 46.52 & IX \\
\hline
\end{tabular}




\begin{tabular}{|c|c|c|c|c|c|c|c|c|c|c|c|c|c|c|c|c|c|c|}
\hline preparation & FX & 84 & 456 & 670 & 1054 & 1450 & 636 & 1600 & 966 & 882 & 296 & 561 & 442 & 208 & & & & \\
\hline \multirow[t]{2}{*}{ Staff ambience } & $\mathrm{F}$ & 5 & 4 & 6 & 10 & 9 & 17 & 19 & 18 & 31 & 17 & 33 & 14 & 17 & \multirow[t]{2}{*}{200} & \multirow[t]{2}{*}{8603} & \multirow[t]{2}{*}{43.01} & \multirow[t]{2}{*}{ XII } \\
\hline & FX & 420 & 304 & 402 & 620 & 522 & 901 & 950 & 828 & 1302 & 629 & 1089 & 364 & 272 & & & & \\
\hline \multirow{2}{*}{$\begin{array}{l}\text { Proximity and } \\
\text { accessibility }\end{array}$} & $\mathrm{F}$ & 12 & 6 & 10 & 8 & 15 & 13 & 8 & 30 & 18 & 24 & 21 & 15 & 20 & \multirow[t]{2}{*}{200} & \multirow[t]{2}{*}{9016} & \multirow[t]{2}{*}{45.08} & \multirow[t]{2}{*}{$\mathrm{X}$} \\
\hline & FX & 1008 & 456 & 670 & 496 & 870 & 689 & 400 & 1380 & 756 & 888 & 693 & 390 & 320 & & & & \\
\hline \multirow{2}{*}{$\begin{array}{l}\text { Wide choice of } \\
\text { menu }\end{array}$} & $\mathrm{F}$ & 35 & 20 & 19 & 17 & 12 & 17 & 15 & 14 & 6 & 5 & 7 & 13 & 20 & \multirow[t]{2}{*}{200} & \multirow[t]{2}{*}{11024} & \multirow[t]{2}{*}{55.12} & \multirow[t]{2}{*}{ III } \\
\hline & FX & 2940 & 1520 & 1273 & 1054 & 696 & 901 & 750 & 644 & 252 & 185 & 231 & 338 & 240 & & & & \\
\hline \multirow{2}{*}{$\begin{array}{l}\text { Quality and taste } \\
\text { of food items }\end{array}$} & $\mathrm{F}$ & 15 & 6 & 17 & 5 & 17 & 21 & 26 & 8 & 17 & 5 & 17 & 24 & 22 & \multirow[t]{2}{*}{200} & \multirow[t]{2}{*}{9368} & \multirow[t]{2}{*}{46.84} & \multirow[t]{2}{*}{ VIII } \\
\hline & FX & 1260 & 156 & 1139 & 310 & 986 & 1113 & 1300 & 368 & 714 & 185 & 561 & 624 & 352 & & & & \\
\hline \multirow{2}{*}{$\begin{array}{l}\text { Spending time } \\
\text { with friends/ } \\
\text { relative }\end{array}$} & $\mathrm{F}$ & 34 & 39 & 32 & 23 & 16 & 9 & 6 & 12 & 4 & 1 & 9 & 3 & 12 & \multirow[t]{2}{*}{200} & \multirow[t]{2}{*}{12419} & \multirow[t]{2}{*}{62.09} & \multirow[t]{2}{*}{ I } \\
\hline & FX & 2556 & 2964 & 2144 & 1426 & 928 & 477 & 300 & 552 & 168 & 37 & 297 & 78 & 192 & & & & \\
\hline \multirow[t]{2}{*}{ Home delivery } & $\mathrm{F}$ & 25 & 16 & 21 & 29 & 26 & 10 & 9 & 10 & 16 & 15 & 12 & 6 & 5 & \multirow[t]{2}{*}{200} & \multirow[t]{2}{*}{11328} & \multirow[t]{2}{*}{56.64} & \multirow[t]{2}{*}{ II } \\
\hline & FX & 2100 & 1216 & 1407 & 1798 & 1508 & 530 & 450 & 460 & 672 & 555 & 396 & 156 & 80 & & & & \\
\hline Total & & 200 & 200 & 200 & 200 & 200 & 200 & 200 & 200 & 200 & 200 & 200 & 200 & 200 & & & & \\
\hline
\end{tabular}

(Note: $x=$ Scale value: $f=$ Number of respondents: $f x=$ score

From the analysis, the majority of the respondents are influencing to prefer branded fast food restaurants is spending time with friends/ relatives, home delivery and wide choice menu.

\section{Consumers' Perception Towards Branded Fast Food Restaurants - ANOVA}

The relationship between the selected independent variables (age, gender, marital status, educational qualification, occupational status, consumers' preference, frequency of visit) and consumers' perception towards branded fast food restaurants have been examined by framing a null hypothesis. The framed null hypothesis has been analysed with ANOVA at 5 per cent level of significance. It is shown in the following Table 3.

TABLE 3 Relationship Between Independent Variables and Consumers' Perception Towards Branded Fast Food Restaurants-ANOVA

\begin{tabular}{|c|c|c|c|c|c|c|c|}
\hline Variables & $\begin{array}{l}\text { Source of } \\
\text { variation }\end{array}$ & Sum of square & Df & Mean Square & F- Ratio & $\begin{array}{l}\text { F- Table } \\
\text { value }\end{array}$ & Result \\
\hline \multirow[t]{3}{*}{ Gender } & Between groups & 1.591 & 2 & .796 & \multirow{3}{*}{3.246} & \multirow{3}{*}{2.99} & \multirow{3}{*}{ Insignificant } \\
\hline & Within groups & 48.284 & 197 & .245 & & & \\
\hline & Total & 49.875 & 199 & & & & \\
\hline \multirow[t]{3}{*}{ Age } & Between groups & 22.326 & 2 & 14.663 & \multirow[t]{3}{*}{13.078} & \multirow[t]{3}{*}{2.99} & \multirow[t]{3}{*}{ Insignifican } \\
\hline & Within groups & 220.869 & 197 & 1.121 & & & \\
\hline & Total & 250.195 & 199 & & & & \\
\hline \multirow[t]{3}{*}{ Marital status } & Between groups & 1.349 & 2 & .675 & \multirow[t]{3}{*}{2.738} & \multirow[t]{3}{*}{2.99} & \multirow[t]{3}{*}{ Significant } \\
\hline & Within groups & 48.526 & 197 & .246 & & & \\
\hline & Total & 49.875 & 199 & & & & \\
\hline \multirow{3}{*}{$\begin{array}{l}\text { Educational } \\
\text { Qualification }\end{array}$} & Between groups & 8.914 & 2 & 4.097 & \multirow[t]{3}{*}{3.769} & \multirow[t]{3}{*}{2.99} & \multirow[t]{3}{*}{ Insignificant } \\
\hline & Within groups & 214.161 & 197 & 1.087 & & & \\
\hline & Total & 222.355 & 199 & & & & \\
\hline \multirow[t]{3}{*}{ Occupational status } & Between groups & 5.603 & 2 & 2.802 & \multirow{3}{*}{1.527} & \multirow{3}{*}{2.99} & \multirow{3}{*}{ Significant } \\
\hline & Within groups & 361.392 & 197 & 1.834 & & & \\
\hline & Total & 366.995 & 199 & & & & \\
\hline \multirow{3}{*}{$\begin{array}{l}\text { Consumers } \\
\text { preference }\end{array}$} & Between groups & 3.176 & 2 & 1.588 & \multirow{3}{*}{0.815} & \multirow{3}{*}{2.99} & \multirow{3}{*}{ Significant } \\
\hline & Within groups & 384.004 & 197 & 1.949 & & & \\
\hline & Total & 387.180 & 199 & & & & \\
\hline \multirow[t]{3}{*}{ Frequency of visit } & Between groups & 3.093 & 2 & 1.547 & \multirow[t]{3}{*}{1.478} & \multirow[t]{3}{*}{2.99} & \multirow[t]{3}{*}{ Significant } \\
\hline & Within groups & 206.187 & 197 & 1.047 & & & \\
\hline & Total & 209.280 & 199 & & & & \\
\hline
\end{tabular}

From the analysis, it is found that there is no significant relationship between gender, age, educational qualification and perception level of the respondents towards branded fast food restaurants. It is also revealed that there is a significant relationship between marital status, occupational status, consumers preference, frequency of visit and perception level of the respondents towards branded fast food restaurants.

\section{SUGGESTIONS}

The following suggestions are made based on the findings of the present study:
- The study reveals that the maximum of the respondents are influenced by spending time with friends/relatives, home delivery and wide choice of menu towards branded fast food restaurants. Therefore, it is suggested that the service provider of the fast food restaurants should undertake the training programme often to the sales personnel in order to improve the service quality.

- It is found from the analysis that there exist a significant relationship between frequency of visit and consumers' perception towards branded fast food restaurants. Hence, it is suggested that the management of fast food restaurant should endeavour to improve on 
their empathy by providing more care and personalised service to consumers in order to make them to revisit the restaurants again.

- It is inferred that majority of the respondents' opinion about the cost of branded fast food restaurant is too expensive. Hence, it is suggested that the service provider fast food restaurant should offer their products price are nominal to the customers according to the region.

\section{CONCLUSION}

The emergence of the fast food restaurant has transformed urban food culture in India to some extent. In India, fast food culture emerged after independence. Eating at home used to be a significant aspect of Indian culture. However, over a period of time, with a growth in the number of nuclear families, economic growth and increasing per capita income as well as globalization, fast food culture gained prominence.

With the liberalization of the economy in 1992, new multinational fast food giants targeted India as a huge potential market with their outlets. Burger King, Pizza Hut, Domino's Pizza, McDonald's and KFC outlets are functioning in shopping malls and other public areas. Changing consumer behaviour and favourable demographics led India to witness a tremendous growth in fast food restaurant industry.

The study inferred that the maximum of the respondents prefer Barbeque Nation fast food restaurant and most of the respondents are highly influenced by spending time with friends/ relatives. Hence, it can be concluded that the management of fast food restaurants may improve the level of perception and satisfaction if the above mentioned suggestions are implemented.

\section{REFERENCES}

[1] Shodhganga.inflibnet.ac.in/bitstream/10603/3077/9/09

_chapter\%201. Pdf-Introduction to service sector around the world.

[2] C.G.E Salami and R.T Ajobo(2012), Consumer Perceptions about Fast Food Restaurants in Asaba. Global Journal of Management and Business Research e-ISSN: 2249-4588, p-ISSN: 0975-5853. Volume 12, (Issue 1),pp, 1-5.

[3] Y.Prabhavathi et al., (2014), Consumer Preference and Spending Pattern in Indian Fast Food Industry, International Journal of Scientific and Research Publications, Volume 4, Issue 2, ISSN 2250-3153 pp 14. 